\title{
血漿蛋白分解酵素活性値の日内変動
}

\section{Diurnal Rhythm in the Activity Level of Plasma Proteolytic Enzyme}

\author{
新潟大学医学部㣚生学教室 (主任 渡辺厳一教授) \\ 松 尾 $\checkmark \neq$ 子 \\ Makiko Matsuo \\ Department of Hygiene, Nïgata University School of Medicine \\ (Director: Prof. G. Watanabe)
}

\section{まえがき}

血清, あるいは血漿が, 酸性メディアムで蛋白分解能 をもつことは，古くから知られていた。

近年, 胃に由来する pepsinogen の存在が血清, 血漿 中に確認された。すなわち, 胃粘膜分泌腺から直接血流 中に分泌された pepsinogen が血液 pepsinogen (blood plasma pepsinogen ${ }^{11}$, blood pepsin ${ }^{21}$,blood pepsinogen ${ }^{31}$ plasma pepsinogen ${ }^{4}$, serum pepsinogen $\left.{ }^{5}\right)$ となり，さ らに腎加排泄されて尿 pepsinogen (uropepsin)，とな

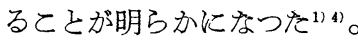

さきに桜井 ${ }^{61}$ は, uropepsin (以下 Up. と略す) の日内 変動について報告し，Up. 排泄值は，夜間睡眠時最低で あり，朝労作の開始前後にもつとも高く，漸次夜に向办 つて下降するょうな，あざやかな変動をした，と述べて いる。とのこと注当然, 血液 pepsinogen (以下 Bp. 已略 す）に，日内律動のあるであろうことが推測されるので ある。しかし，強い恒常維持機構の影響をうけるである 亏 Bp.の血中濃度と, 単位時間中排泄されるUp.の尿中 量とでは，扮のずから生理的律動の様相が異なると考え られる。乙れまでに Bp.の日内変化について扮招まかな

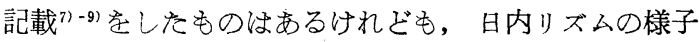
について詳細な観察をしたものは見当たらない。そこで 私は，Bp.の日内律動の有無を確かめ,ささら Up. のそ れと比較するため，以下本論交に述べるような観察をお こない，知見を得たので，その大要を紹介する。

\section{方 法}

\section{被検者}

起床，食事，就寝なぞを時間的に一定にしながら，20
墄から38墄までの健康成年女子 28 人について, まず, 覚 醒後直ちに (午前 6 時) 臥床させたまま血液を採取し, 以後 3 時間ごとに採血し， 1 日計 6 回血液資料を採つ た。な招，測定日とその前日は，激しい学作招よび特別 な勤務なぞを避けさせ, 可及的普通の生活をさせた。ま た，月経执よび排卵日など，とくに異常な生理的影響が 考慮される日を除いたととは勿論である。

\section{測定法}

血漿 pepsinogen (以下 Pp. と略す) の測定には，多く の方法がある。現在主として用いられているのは Anson の原法 ${ }^{10}$ 打よびその修正法 ${ }^{12}$ 2) 11)-13)である。私は桜井, 田辺ら ${ }^{14)}$ ともにそれについて吟味検討を加え, さきに 発表したので，ここでは，打掠よその理解ができるよう 簡単に記載する。

この研究は, Spiro 法"2) 準执した。すなわち, 2.5 $\%$ Bacto-hemoglobin 溶液と $3 / 10$ N塩酸を 3 容対 1 容の 割合混合して基質とする。

一この基質10ccに，あらかじめ二重鉴酸塩で処置した血 墏 $2 \mathrm{cc}$ と蒸溜水 $3 \mathrm{cc}$ を加えて総量 $15 \mathrm{cc}$ とし, その中少ら 6 ccずつ 2 本の試験管にとり, 一方には直 $5 k 3 / 10 \mathrm{~N}$ 三塩化酶酸10ccを加えて除蛋白した。との試駼管 2 本を 同時に $37^{\circ} \mathrm{C}$ 恒温槽につけ 24 時間放置する。24時間後, 他の試験管へ $3 / 10 \mathrm{~N}$ 三塩化酷酸10ccを加えて除蛋白し, それぞれ 東洋滤紙 No. 131 (Whatman No. 3 に相当) で滤過する。この濾夜 $5 \mathrm{cck} 5 / 10 \mathrm{~N}$ 水酸化ナトリウム 10 ccを加えてアルカリ化し，さらに phenol 試薬 $3 \mathrm{cc}$ を添 加し発色させる。 5 〜 10 分後 $10 \mathrm{~mm}$ の厚さの液槽を使い filter S 75で比色した。かくして得た值を標準曲線にてら し, tyrosine の microgram/cc 数に换算し, 2 つの資 
料の値の差をむつて求めるPp.の活性值とした。

な招，後述するように，血液中の pepsinogen の所在 については, 血漿11122,15)，血清1112), 繊維素 ${ }^{16117)}$, 赤血

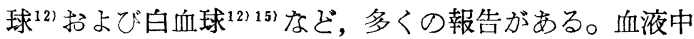
pepsinogenのうち血漿扢よび血清中の酵素は，胃由来 のものであるけれぞも，血球のそれが由来に関してはい

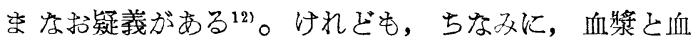
清中の pepsinogen 活性度は変らない, とする報告 ${ }^{111-13,}$ がある。すでに述べたよに，私は，血墏をもつて資料 とした。

\section{結 果}

健常成年女子 28 人について各個の測定結果は第 1 表に 示すと括りである。これらの測定值を仔細にみると, 変

\section{第 1 表 血墏 pepsinogen の日内変動}

（個人表）（ $\mu \mathrm{g}$ tyrosine/cc plasma）

\begin{tabular}{|c|c|c|c|c|c|c|}
\hline $\begin{array}{c}\text { 被検者 } \\
\text { 番号 }\end{array}$ & $\begin{array}{l}\text { 午前 } \\
6 \text { 時 }\end{array}$ & $\begin{array}{l}\text { 午前 } \\
9 \text { 時 }\end{array}$ & 正午 & $\begin{array}{l}\text { 午後 } \\
3 \text { 時 }\end{array}$ & $\begin{array}{l}\text { 午後 } \\
6 \text { 時 }\end{array}$ & $\begin{array}{l}\text { 午後 } \\
9 \text { 時 }\end{array}$ \\
\hline 1 & 499 & 589 & 467 & 506 & 454 & 468 \\
\hline 2 & 455 & 487 & 458 & 403 & 394 & 421 \\
\hline 3 & 429 & 448 & 394 & 380 & 420 & 384 \\
\hline 4 & 511 & 672 & 516 & 571 & 458 & 479 \\
\hline 5 & 441 & 487 & 451 & 418 & 431 & 411 \\
\hline 6 & 259 & 284 & 231 & 250 & 286 & 235 \\
\hline 7 & 506 & 542 & 524 & 491 & 449 & 462 \\
\hline 8 & 356 & 336 & 406 & 323 & 329 & 342 \\
\hline 9 & 478 & 519 & 483 & 522 & 504 & 498 \\
\hline 10 & 397 & 534 & 484 & 502 & 487 & 473 \\
\hline 11 & 539 & 625 & 454 & 456 & 449 & 403 \\
\hline 12 & 426 & 451 & 491 & 473 & 455 & 430 \\
\hline 13 & 679 & 701 & 668 & 640 & 647 & 622 \\
\hline 14 & 384 & 404 & 361 & 365 & 410 & 370 \\
\hline 15 & 448 & 464 & 554 & 370 & 496 & 465 \\
\hline 16 & 519 & 508 & 574 & 481 & 503 & 515 \\
\hline 17 & 466 & 489 & 441 & 424 & 390 & 428 \\
\hline 18 & 231 & 225 & 249 & 246 & 247 & 221 \\
\hline 19 & 233 & 165 & 220 & 177 & 190 & 189 \\
\hline 20 & 327 & 350 & 368 & 333 & 359 & 360 \\
\hline 22 & 270 & 241 & 278 & 258 & 258 & 247 \\
\hline 23 & 333 & 311 & 291 & 298 & 295 & 289 \\
\hline 24 & 402 & 386 & 393 & 406 & 422 & 404 \\
\hline 25 & 473 & 391 & 389 & 398 & 419 & 377 \\
\hline 26 & 467 & 415 & 419 & 440 & 433 & 431 \\
\hline 27 & 347 & 294 & 305 & 315 & 315 & 312 \\
\hline 28 & 401 & 441 & 448 & 455 & 470 & 467 \\
\hline
\end{tabular}

動の型にしたがつて，3群に分けるととができる。その 模様恃第 1 図にみるとおりである。第 1 群は午前 9 時に 最高值を有するものであり 28 例中 13 例，第 2 群は正午に 山を描くもので 9 例, そして, 第 3 群は前 2 つ類型に 属さないもの, すなわち, 覚醒直後, あるいは夕方に高 いか，または，医とんご変化のみられないもの6例であ る。

さて,これら 3 群をあわせ, 平均したものが第 2 図であ る。この図から明らかなように Pp. は，覚醒時すでに

\section{第 1 図血將 pepsinogen の日内変動(個人)}

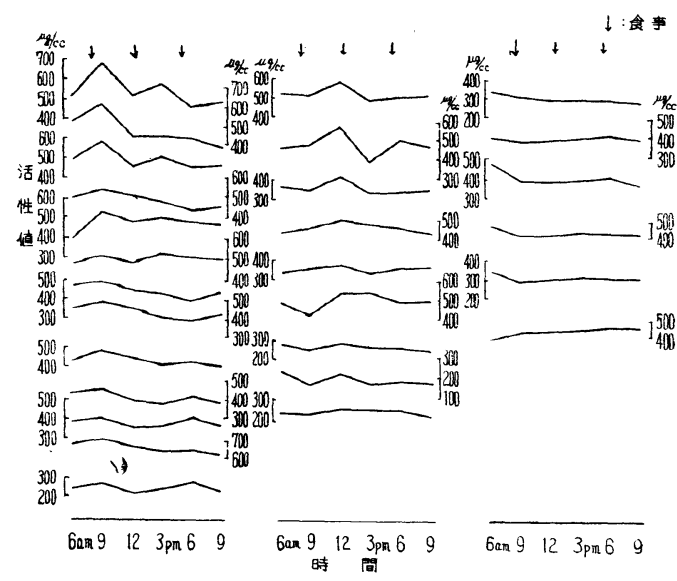

第 2 図血漿 pepsinogen の日内変動 (女子28例)

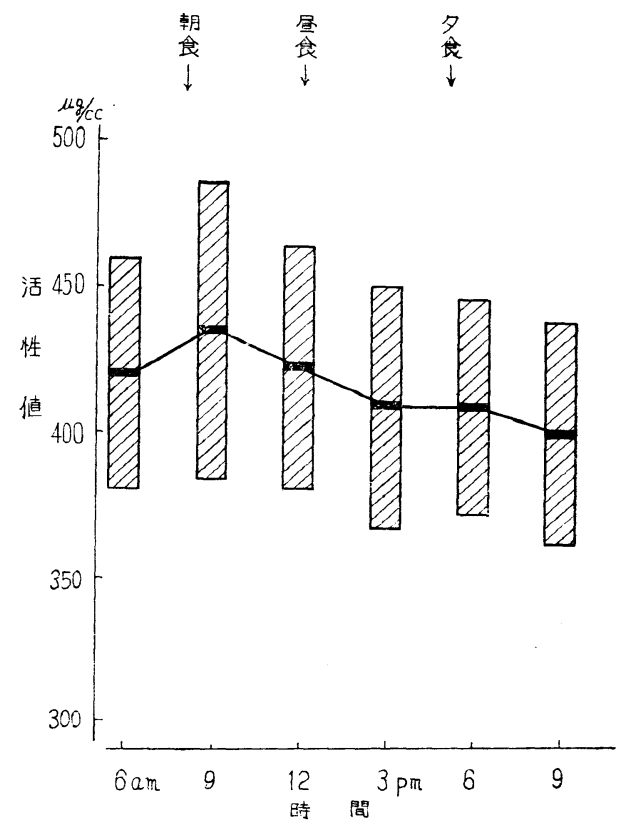


高く, 起床後さらに上昇して午前 9 時に最高値となり, 午 後から夕方にかけて次第に低下し, 午後 9 時に最低とな るょうな日内律動曲線を描いたのであつた。困中各棒の 長さは,母集団平均値 $95 \%$ 信頼限界の幅を示し,棒の中央 の横線は, 標本平均值を示すものである。第 2 図でみる ように, 午前とくに朝方高い Pp. 活性值が, 午後から夕方 に向かつて淵減してゆく傾向に対し, 回帰直線を求め, 実測値の日内変動とともに描いたものが第 3 図である。

\section{第 3 図血墏 pepsinogen の日内変動 (回帰直線)}

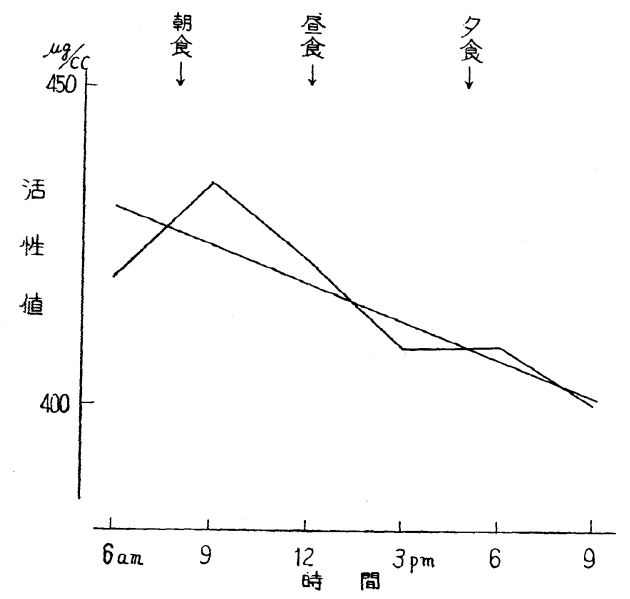

そこで，個々6 回の测定值をもつ28例のすべての数值 につき，回帰を含めた分散分析をおこならに，結果は第 2 表に示すようになつた。時刻間変動, すなわち, 朝活性

\section{第 2 表 血將 pepsinogen の日内変動} 回帰を含めた分散分析

\begin{tabular}{lr|r|r|r|c|c}
\hline 要 因 & 平方和 & 自由度 & 平方平均分散比 & 危険率 \\
\hline 個 体 差 & 1732682 & $28-1$ & 64173.4 & 33.9 & $\mathrm{p}<0.001$ \\
時刻間変動 & 21898 & $6-1$ & 4379.6 & 2.31 & $\mathrm{p}<0.05$ \\
残 & 差 & 160610 & $27 \times 5$ & 1897.0 & & \\
\hline 計 & 1915190 & $167-1$ & & & \\
\hline
\end{tabular}

值が高く，夜低い逐時的傾向のあるのは $5 \%$ 以下の危険 率で有意だといえるのである。また, 第 2 図から, Pp. 活性値にはかなりの個体間の差があることがわかる。

けれぞも，第 2 表の分散分析により，0.1\%以下の危 険率でそれは有意であつた。換言すれば, Pp. 活性値に は相当大きな個体差があるけれぞも，各個体はそれぞれ 固有の水準で上述のような活性値の日内変動をしている のだというここができるのである。そこでさらに，各時
刻間相互の活性值変動の大きさ念のため検定してみる に，第 3 表のような結果を得ることができた。

\section{第 3 表 時刻間の活性値変動の大きさの検定}

\begin{tabular}{r|r} 
午前 6 時と午前 9 時 & $\mathrm{p}<0.01$ \\
午前 6 時と午後 9 時 & $0.01<\mathrm{p}<0.02$ \\
午前 9 時と午後 3 時 & $0.01<\mathrm{p}<0.02$ \\
午前 9 時と午後 9 時 & $\mathrm{p}<0.01$ \\
\hline
\end{tabular}

以上述べたように, Pp. に注明らかな日内変動が存在 し, 律動の形式洨, さきに桜井が報告(6)した Up.の日内 変動々相似したあのであるととがわかつた。

しかし,両者を仔細任検討すると, 次のような差異が認 められる。第 1 k Pp. の日内変動は Up. のそれょり個 体差が大きく, 律動形式は不安定である。乙れは当然考 えられるところであり, 後者は一定時間内の平均活性值 が示す変動であるのに対し，前者はある一定の時刻の血 中活性值が示す変動である。したがつて, 個々の值は時 刻時刻に怙ける一切の刺战の影響をうけやすいのであ る。第 2 に律動の振幅は Up.ではるかに大きく, Pp. でかなり小さい。Pp. 注恒常維持機構の影響を強くうけ るから, 終日の值が比較的安定なのである。いいかえれ ば，律動振幅が狭い。Pp. の律動振幅を小さくするため には，Up. の律動振幅を大にしなければならない。すな わち, Up. の日内律動の幅が大であることは，Pp.のそ れを小さくするための恒常維持機構の顥現なのである。 第 3 K, Pp. では午前の山が早くあらわれ，Up. では遅 くあらわれる。Pp. の変化が Up. の変化に先行するで あろろとと快，当然考元られるととろであろう。

\section{考 案}

\section{I. 血中 pepsinogen の生理的意義}

血清, 血漿が，酸性メディアム中で蛋白分解能定も つととは，Saxl (1915年)をはじめ Leoper と Debray， Gottlieb, Kleinman そ Schaar, Kammner, Peranio, Br-

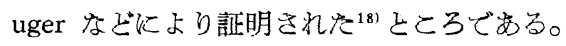

1952年 Mirsky ${ }^{11}$ は，健常人の血漿が酸性のもとに蛋 白分解能を有するととを詳述して, 次の 3 つの系列に分 けた。

その1は, pH 3.5〜 4の間で活性を有し $\mathrm{pH}$ 1.5では 不活性化されるすの゙，胃の存在に虹無関係である。そ の 2 は， pH 1.5〜 3でよく作用するが，pH がたとえ 7 以上になつても活性があり, しかも, 胃の存在には関係 がない。その 3 は, $\mathrm{pH}$ 1.5 3 で最高の活性を有し, 
かつ健常胃粘膜の存在が必要で心り,アルカリ化によ って不活性化される。

彼は以上の各系列の酲素索説明して, 次のよらに述べ ている。すなわち，第1の系列は, cathepsin によると 思われる。第 2 系列の酵素は, 血嶈の全蛋白分解能の了 ち,ごくわずかの部分を占めるのタである。

胃全剔除術後 Up. は尿中方らまつたく消失するが, 血漿はなお， hemoglobin 基質をわずかに分解する能力 をもつ。それは抬そらく，乙の群の䣼素作用によるもの であり, しかむ, pepsin 以外の蛋白分解醉素によるも のであろろ, としている。ところが Hirschowitz ${ }^{122}$ 怆, この現象を説明し，加えた血獎蛋白が塩酸で加水分解さ れ生じたもので, 非䤃素的なものだ, と主張している。 第3の系列は，pH 1.5〜 3で最高の活性を示す。血獎 蛋白分解能の大部分はこれによるものである。とれが pepsin に添㐫ならない。この際, pepsin は血液固有の $\mathrm{pH}$ で, 急速に非活性化される。そこで, 胃から循環 系へ分泌されるのは，おそらく pepsinogen であり, pH 1.5〜 3 で自己触媒的に pepsin へ変化するのであろろ, 己Mirsky は述べている。Hirschowitz" は，Bp.が量的に あまり少なすぎるので，血液から分離するとと就できな いが，とれとそ pepsinogen である，といつた。すなわ ち, 未処置血漿の蛋白分解醉素のほこんど大部分の活性 につき, $\mathrm{pH}$ や温度などを変化せしぬ, pepsinogen との 異同を確かめたのである。

胃全剔出後，Bp. が急速に血漿から消失する1)ととは， 本醉素が胃に由来するととを示すものでなければならな い。な抢，乙の際 Hirschowitz ${ }^{12)} は$, 胃を Billroth I の術式で部分切除したけれども, Pp. が格別減少しなか つたところから，胃底部にその分泌源があるのだ，とい つた。

また Kowalewsky ${ }^{19}$ は、イメに histamine を投与する 前後のP P. 学, 胃動脈, 胃静脈, 門脈, 肝静脈, 脳静 脈内血液で測定した。その結果, pepsinogen 濃度は, 胃 動脈より胃静脈に高く，しかむとの差は， histamine 投 与後目立つて大となつた。 pepsinogen 濃度は胃静脈で もつとも高く，末梢にゆく漂と漸次減少した，という。 この際 histamine 泣 P p. の上昇已同時飞, 胃内挖への pepsin (以下Gp. と略す) 排泄，おょび，胃の遊離酸な らずに胃液量の上昇をも誘起した。彼はしれらのとと から, pepsinogen が胃粘膜の醭素細胞から直接血中へ 内分泌されるのであろう，と推論している。ちなるに， Pp. は肝臟で変化をうけない, としている。

かくして，Bp．が㥜粘膜から分泌される形式は，一種
の内分泌上考光られる。しかし，とのものの生体内に拉 け名意義やその般割は、今日な技不明である。

Bp.の血中所在に関し，まず Calcar ${ }^{15)}$ 快，イヌの血 漿と白血球中にあるととを記述した。また， Stadelmann ${ }^{16)}$ Łeo $^{17}$ は, pepsinogen と fibrinogen が結合してい る, といつたが, のちになつて Fuld と Hyrayama ${ }^{201} に$ より否定された。Hirschowitz ${ }^{12}$ 沈, 血漿と血清で pepsinogen 濃度は同一であつた, しいう。Chinn ${ }^{11}$ も，血清 と血漿の蛋白分解能について比較したが, 差はなかつ た, と述べている。さらに Hirschowitz ${ }^{12)}$ は, 赤血球や 白血球中にもとの存在を認めた。

しかし, 胃全剔後白血球中の pepsinogen 濃度が変ら なかつたことから, 白血球中の醰素は白血球内でつくら れたものであるか, あるい结胃からの䤃素をととに集め て保留しているので方ろう, 上推論した。白血球中に含 まれる酵素の総量山, 胃由来の血漿中のものに比し, 非 常に少ないのである。

Bp. の臨床的知見として, $\operatorname{Hoar}^{13)}$ は, 上部消化器系潰 瘍, 胃癌, 悪性賀血, 胃全剔出後などに抢ける Bp.の変 化について記載し, かかる際の Bp.活性値の測定恃, 診 断を確実にする点で，Up. 測定にまさる, こ述べている。

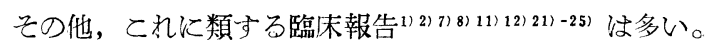
また，Bp．と奸娠の関係を追究した報告 ${ }^{26}$ もある。

Bp. 濃度に影響をあたえる因子として，まず食事提 取をあげるととができる。Gottlieb27) は、イメについ て, パン食から肉食に变えたところ, 血中ならびて尿中 pepsinogen が増加した, 乙報告している。一方 Mirsky” は, 健康人につき, とる食事の組成を変えつつ, 食事前 後，30〜60分間隔で斬続的汇採血した。Pp. の活性值 を比較したけれどむ, 炭水化物, 脂肪, 蛋白質を別々に あるい络三者を混合してあたえた影響の差加認められ ぬ,といつた。さらに,彼はイ又を6日間断食させたが， Pp. は変化しなかつた，と報じている。その他，Spiro

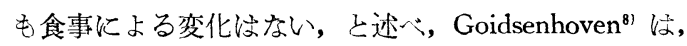
24時間餓餓の前後を測定して, 大した差が只られなかつ た, といつている。 $\mathrm{Hoar}^{13)}$ 注, 食事の影響を時間を逐 つて, 連続的に測定したけれども, その間 2 回とつた食 事の影響を文なかつた，と報じている。

Gp., Up. Kつきタバコ ${ }^{282}{ }^{291}$, コーヒー ${ }^{301}$, 茶 ${ }^{311}$ など の影響を記載はあるけれどあ，Bp. についての記載 は見当たらない。

薬物の影響についての記述む数多く及られるが，その 間統一した知見は得られていない。

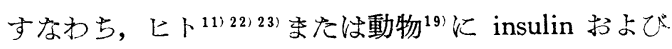


histamine を投与すると Bp. は上昇するとの説 ${ }^{1922)}$ と， とれを否定 ${ }^{11}$ するものとがある。

また, histamine では上昇し, insulinで下降する，上 いう報告 ${ }^{23)}$ ある。chlorpromazine 投与では下降する221 という。次に, atropine 投与性 Bp.を下降せしめる, と するすの ${ }^{22)}$, 変化しない23)，と述へているものなどがあ る。さらにVarro ${ }^{32}$ は, adrenalin $0.4 \mathrm{mg}$ 投与で Bp., Up. ともに増加せずと報じ，Hoar ${ }^{131}$ は，イ邓の insulin 低血糖による迷走神経刺战, あるいは, 直接の電気刺战 をしてあ，Pp. は上昇しなかつた，といつている。

てのょうにして自律神経戍, またはその刺战と Bp. 之 の関係は明らかでないところが多い。

運動との関係について, 桐淵 ${ }^{33)}$ は Up. と関係あり, と報じているが，Bp. に対する影響を論じたものは見当 たらない。

さて, 近年, Bp. 濃度と副腎皮質機能との関係が論ぜ られてきた。Bp. 活性値は皮質機能に影響される，とい うのである。

Varro ${ }^{32}$ は，Pp. 濃度と皮質活性につき，次のような

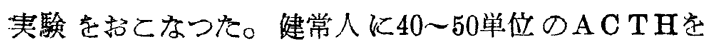
1 回筋注したのち，0，1，2，4，6時間目の血液中 の pepsinogen を定量した結果, 24 人中 23 人に捛いて, Bp. 活性值は 120 分でピークに達し， 6 時間後に初めの レベルに帰つた。その増加率は14〜49\%であつた，とい う。さらに彼㹥, 慢性副腎不全患者 7 人にACTHを投 与したが，Bp. 活性值の增加を及なかつた。そして，A C TH投与後の Pp. 值の変動を観察卞ることは, 副腎皮 質予備力の有用な検査法である, と結論している。ま

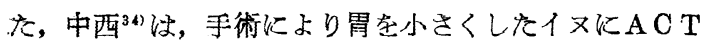
H毎日 $20 \mathrm{mg}$ を 7日間筋注したととろ, Bp. 技よび Up. がともに注射直後上昇し, 第 3 日に最高值を示し

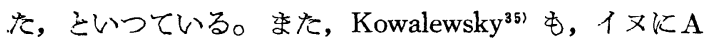
C THをあたえたところ, Pp. は増加した，と報じてい る。さらに中西 ${ }^{36}$ 性, Pawlow 氏小胃1又に, cinchophen による胃小湾部潰瘍を発生せしめたのち, Thorn 氏テストを执てなつたととろ Pp. 捛よび Up. の活性値 が, 尿 $17 \mathrm{KS}$ 量, 17-OHCS 量々密接な相関を示したと とから, Pp. やUp.の動摇は, 胃の主細胞機能が完全な 办き，副腎皮質活性を表わす，と報告している。

逆に, Bp. 活性值と副腎皮質機能の関係を否定するも のは，以下の上抬りである。すなわち， $\mathrm{Gray}^{377}$ は，AC THまたは皮質ステロイド投与により, 胃酸, Gp., Up. なぞが 100〜 200\%上昇したにも拘らず，Bp. 恔変化 しなかつた, といつている。また, $\mathrm{Hoar}^{13)}$ は, ヒト
ては, ACTH, cortisone, comp. F の治療量が Bp.を上 犁させなかつたが, イヌに ACTHを静注すると, 胃静 脈の Pp. 活性値は末梢血液のものに比して明ら汃増加 した, といつている。また Woodward ${ }^{5)}$ が, ヒトにAC THを投与したとしろ, 血清 pepsinogen (以下 Sp. と略 す) は変化しなかつた, という。 Shapiro ら ${ }^{31}$ は, steroid ホルモン連続投与を弓けた 4 人の Bp. 活性値はとく に正常と変りなかつた, と。また, イヌ,ネコ, シロネ ズミに，ACTH，皮質ホルモンをあたえたととろ，副 腎皮質機能が明らかに反応を示したにも拘らず，Bp. 活 性值性格別增加しなかつた，と述べている。

さて，Bp. が比較的一定であるととの機序を説明し て, Hirschowitz" A C T H老投与すると，腎クリアランスが増加するため Up. 量は增加するが， Bp. 濃度は影響されない。靕クリ アランスの增加によつて血中加失われる Bp.は, 胃粘 膜少ら常に補給されていて, 比較的一定の值を保つてい るのである, と。一方, 十二指腸潰瘍時は, とくに腎ク リアランスが増大しないので Up., Bp. 両活性值とむに 上昇するのだ，としている。

Bp. 活性值とストレスの関係について竹腰 ${ }^{381}$ は, Sp. が手術亩前にすでに高く，術後もその高值が続くのを文 て, 肉体的ストレスも Pp. 汇影響を及㳊すが, 精神的ス トレスもまた充分影響を及隹すむのだといつている。 また, 中西 ${ }^{31}$ 万の外科手術後 3 日目に Bp. 方最高活性を 示した，などの記載もある。Hoar ${ }^{13}$ あほ快同様のととを 報じている。

さて, Gp., Bp., Up. 3者の関係について報じたすの は以下のようである。まず, Up. と Gp. との関係につい て Janowitz-Hollander ${ }^{391}$ は, 基礎分泌時主細胞は, pepsinogen $99 \%$ 胃腔に排出し，1\%を血中に分泌し，乙 れが Up. として尿中へ排泄されるのだ，としている。 Gray 万(0)も，0.9〜2.4\%，平均 1.4\%が血中に分泌 されるといい, この際, 内外分泌比は，ACTHまた cortisone を投与しても, 比較的一定であつた, と誌し ている。次に, Gp. とBp.の関係について報じたのは 次のようである。

Hirschowitz ${ }^{12)}$ は, ヒト 8 人について連日 Bp. を測定 し, 個々の時刻変動はかなりあつたが, 同時に測つた Gp. 上の関係は昖捛むね一定で，2 者の間に高い相関を 認めている。末た, Spiro ${ }^{23)}$ は, 胃機能の正常なヒトへ, histamine を投与すると Gp. が增加するが，とのときの Gp. を “histamine 投与で生じた基礎 Gp.”を名づけ, “wash-out. phenomenon”なのだといつている。との場 


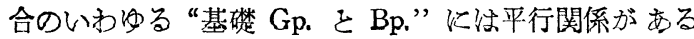
ことを認めている。Kowalewsky ${ }^{19}$ も，イメに histamine をあたえると Gp., Bp. ともに上界し，またモルモット でも同様のととが夕られる，と報告している。

との国の研究報告として, 日野 ${ }^{21}$ は, 7 人につき空腹 時の $\mathrm{Gp}$. と Pp. 量を測定し相関関係なしとしているの に対し, 竹腰 ${ }^{11}$ は, 健常なヒト 41 人で測つた Up. とBp. 両活性值の間には相関係数 0.78 で示されるょうな関係が あつた，と報じている。

さらに, Gp., Up., Bp. 3 者を同時に測定した報告も かなり多い。これら 3 者の間に, 相関を認めるものは次 のようである。

Goidsenhoven $^{81}$ 快, 正常人, 上部消化器系疾患の者, 無酸症などについて測定し，Gp. と酸度，Sp. とUp. に正の相関があつた，としている。

中西 ${ }^{42}$ は, Pp., Up., Gp. いずれも十二指腸潰瘍では 高く, 胃癌では低く, 乙れら 3 醉素の間には明らかに 相関関係为認められる, と述べている。福地 ${ }^{221}$ 431 44) は, Gp., Up., Bp. の消長が夜間の基礎分泌 ${ }^{22}$ に执いてもな 怙よく相関した，と述へ，乙れに胃分泌刺战剂 ${ }^{43}$ 老あた えても 3 者がよく平行するところから, pepsinogen の外 分泌と内分泌怯じ分泌支配である，といつている。

これに反し，乙れら 3 者間 Bp.のみ快比較的一定であ る, とする説がある。すなわち Woodward ${ }^{51}$ は, 偽食, A C TH刺㦸, urecholine 投与で, Gp. ならびに Up. は変化したけれぞも，Bp. はすべての場合一定で変化し なかつた，という。また， Gray ${ }^{37 n} も ， \mathrm{ACTH}$ 投与で Up. と Gp. は増加したが, Bp. は変らなかつた, こ報 じている。Hirschowitz" む, A C T H投与で Up. は増 加したが, Bp. と Gp. 梳変化しなかつた，と述べてい る。

\section{II. 血中 pepsinogen の日内変動}

Bp. の日内変動について恬，次のような報告がある。 Hirschowitz" は，13人の正常人につき 2 時間ごと集的 た血中のPp.濃度変化率は, 平均 $7 \%$ あった, と述べ ている。Mirsky”㥙, 健康男子19人の Bp.を 2 4 時間 の間隔で測定したが, とくに日内变動を認好かつた。 末た，Goidsenhoven ${ }^{87}$ む，昼間值之夜間值の間に有意の 差を認められなかつた，と報告している。しかし，以上 の報告には, 採血時刻, 资料採取の条件などが詳しく記 載されていないので, 彼らの設定した測定条件が, 適切 であつたか否か不明である。

私は，既述の上らに健康成年女子 28 人について, 起 床, 食事, 睡眠などを一定にし, 採血時間をこまかく区
切つて得た資料につき Bp.の日内変動を久をのである。 その結果, 多くは朝覚醒時, すでにかなり高く, 起床と ともに上昇し, 午前 9 時に最高值となり, その後夜に向 かつて漸次下降するような曲線孛描いたのであつた。 その傾向は, さきに桜井が報告 ${ }^{6}$ した Up.の日内変動上 よく似た変動であつたのである。しかしながら，との 2 者間に泣, 律動曲線の様子に多少の相違がある。単位時 間中尿へ排泄された Up. と，ある特定時刻の血中濃度 を示す Bp.とでは, 律動上生理的意義を異にするのは当 然である。

胃分泌機能促進の機転から推測して，Bp. の日内律動 に影響を及洼す因子として，末ず第 1 亿食事摄取の影 響が考えられる。桜井 ${ }^{6}$ は, Up. の日内変動を観察した 際, 朝食招よび夕食を久食して，同様な測定をおこな い, これら 2 者の日内律動曲線が基本的に差のないとと を認めた。既述のように, 食䬣の量技よび質が Bp. を 変化せしめるこよはない，という報告" があり，また， 連続的な測定で，その間提取した食事が Bp. 亿影響 しなかつた ${ }^{13)}$ ，とする記載もある。本観察で，食事摂 取が Bp. 日内律動曲線に直接影響していると考えられ る知見は欢られなかつた。第 2 亿考虑すべきは, 自律 神経緊張状態の日内恋動と Bp.のそれとの関係である。 Pierach $^{45}$ は, ヒトの生理機能が 24 時間中律動する有様 を述べ, これは, 自律神経系により強く支配され, かつ 間脳一下垂体一副腎皮質内分泌軸が とれに協約してい る, と述へている。また黒津 ${ }^{46147}$ は, 自律神経の機能形 態学的見地から, Euler'番 は,アドレナリン，ノルアド レナリン尿中排泄量の日内変動からみて, 昼間洨夜間よ りも，より交感神経緊張状態にあると述へている。しか し胃液分泌対する自律神経の支配関係から考元て, 昼 間の交感神経優位が, 胃ペプシン分泌に大きく関与して いるとは思われない。李た，前述のような Bp.の日内変 動と自律神経の関係を直接に結びうる報告す見当たらな

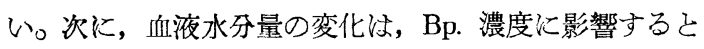
考えられる。Menzel ${ }^{49}$ 打よび細谷 ${ }^{501}$ らは, 血液水分が夜 間增加し，昼間減少する，と報じている。したがつて，

Bp. 濃度が昼に高い傾向は助長されるであろう。

さて，私の得た Bp.の日内変動とすでに述べた Up.の それを比較すると, まず朝覚醒時の值が Bp.活性值で高 いととを注意しなけれい゙ならない。

Polland ら ${ }^{511}$ は, ヒトを約12時間絶対安静卧床せしめ その間，飲食物を摂らせず，すべての刺㦸を避けた状態 で，胃分泌を測定し，乙れを胃の “基礎分泌” と称し た。そして同一人ではてれが㤝定の值を保つものな 
のだ, といつた。

Hirschowitz ${ }^{4)}$ は, pepsinogen の基碟分泌について述 べ, 少なくともとトでは連続的であり, その基碟排泄值 は, 迷走神経刺战 (低血糖による)で得られる最高值の 20〜25\%である，といつている。

夜間睡眠中の Bp.k関する詳細な報告はない。私は朝 6 時覚醒直後, 臥床のまま採血した。

一方, 最低值は, 午後 9 時だつたのである。既述のよ 引k, Bp. 活性值の日内変動上, 副腎皮質機能のそれ飞 の関係を, 後者の信頼できる示標としての尿 17-OHCS 排泄量 ${ }^{527}$-54) ならびに血中17-OHCS ${ }^{55)}$-57 濃度などの過去 に得を知見から案ずるに以下の上うである。

尿17-OHCS の日内律動惊, 朝覚酷後に最高值を示し, 午後名ら下降し, 夜間最低值となる。また, 血夜中 17 OHCS 濃度も，尿中排泄量と相似た周期であるととが 明らかにされている。ただし, 血中濃度の最高を示す時 刻が, 単位時間尿中排泄量の最高值を示す時刻より, い くら早かつた。すなわち, 血中17-OHCS 濃度の日内変

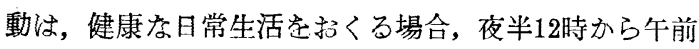
2 時頃に最低となり, 早朝 6 時 $~ 9$ 時頃に最高となるの である。

渡辺ら ${ }^{58}$ は, この間の事情を説明して, 睡眠の初期に は, 外界からの刺战が诚少してて, 皮質ホルモンの分泌が 低下する。しかし相当時間の睡眠をとるここによつて, 前日の活動で消耗した副腎皮質予備力をとりもどす。こ の增加は, 夜半から朝にかけて, 血中ホルモンの上昇と して顥現される，と。

Bp.についても，まつたく同様なととがいえるである う。すでに述べたように, pepsinogen は夜間睡眠時にも 間断なく一部血中へ分泌されている。この研究では睡眠 中の Bp.活性值を測らなかつたけれどす, 血中17-OHCS 之同様, 夕方方ら夜半にかけて漸次下降の傾向にある Bp. は，抬そらく夜半のある時間に最低值を示し，やが て, 副腎皮質予備力恢復とともに早朝にかけ再でその分 泌は上昇に向からものと推測することができる。

このよらなととから朝覚醒直後の值は, 夜半から朝に かけての Bp.増加途上のものでかなり高く, 覚醒と同時 に外界からの刺战が生体に一齊に加わり，Bp. がさら に上昇するのであろう，と思案される。Bp. は，その瞬 間に抢ける pepsinogen 濃度を示すものであり, Up. 柱, 単位時間内に排泄せられた pepsinogen の総排泄量 の平均をあらわすので, その間抢のずから, 時間的ズレ ができるのは当然である。したがつて Bp.の日内変動は Up.のそれのように, 美しい日内リズムを描かぬきらい
がある。そこで小数例の観察では変動に有意差なく, 日 内変動孝確認できないこととなる。したがつて, Bp.の 日内律動をみるためには, かなり多くの例につき, かつ 資料採取の条件を整一にして観察しなければ，律動本来 の姿は得られない,というべきであろう。

\section{総括と結論}

健康成年女子 28 人を被検者とし, 一日の生活様式を可 及的一定にせしめながら, 早朝覚醒時 (午前 6 時) から 3 時間ごとに午後 9 時まで, 1 人につき 6 回の血液資料 を得, 血槳内 pepsinogen 活性值の日内变動を観察し た。測定法は Anson の原法を応用した Spiro 法によつ たのである。

血嶈 pepsinogen 活性值の日内変動様式㤝, 原則とし て午前高く, 午後から夜に加次第に低下するようなも

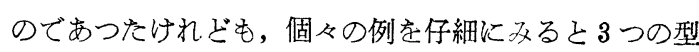
に分けるととができた。すなわち，午前 9 時最高值を示 し，以後夜八向かつて漸次活性值が下降するすの $46 \%$ (13/28), 正午に山を文せ, その前後は漸次活性が低下し ているもの32\% ( $9 / 28)$ ，ほとんぞみる心゙き変動のなか

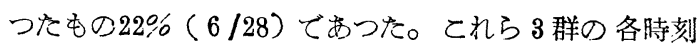
の活性值を総平均して, その日内変動をみる, 朝活性 值が高く, 夜低い傾向は有意水潐を上回るような充分な ものであつた。

かかる血獎 pepsinogen 活性值日内変動は, 副腎皮質 機能の日内変動とその軌を一そするすのである。

ここに述へた血漿 pepsinogen 活性值の日内変動を uropepsin のそれと比較すると，傾向は招招よそ等しい けれぼも, 次の 3 つの点で異なつている。第 1 K, uropepsin の日内変動は, 健康正常生活を打くるがり， 律動の形に個体差が少ない。第 2 に, 最高值を顕現する 時間は，概してて血墏 pepsinogen の方が早く日内変動の 山㳊多少のズレがある。第 3 亿, uropepsin の律動振幅 は血獎 pepsinogenのそれょり社るかに大である。すな わち, uropepsin の顕著な日内変動注, 血獎 pepsinogen の日内変動を可及的少なくするための生体恒常維持の䫓 現に滦かならい。以上の 3 点は, 両者の生理的意義の 相違から当然納得しうべきものであろう。

扎わりK, 渡辺撖一教授のご指導, ご校閲, 桜井忠作 講師ので援助を感謝します。

\section{文 献}

1) Mirsky, I.A., P. Futterman, S. Kaplan \& R.H. Broh-Kahn: Blood Plasma Pepsinogen, I. The 
Source, Properties, and Assay of Proteolytic Activity of Plasma at Acid Reaction, J. Lab. \& Clin. Med., $40: 1,17-26,1952$.

2) Spiro, H. M., A. E. Ryan \& C. M. Jones : The Utility of the Blood Pepsin Assay in Clinical Medicine, New Engl. J. Med., $253: 7$, 261-266, 1955.

3) Shapiro, A. P., J. Melhado, A. Fox \& J. La$\mathrm{mm}$ : Effect of Stimulation of Adrenal Cortex on Blood Pepsinogen in Animals and Man, Proc. Soc. Exper. Biol. \& Med., 93 : 2, 334338, 1956.

4) Hirschowitz, B. I. : Pepsinogen : Its Origins, Secretion and Excretion, Physiol. Rev., $37: 4$, 475-511, 1957.

5) Woodward, E. R., L. Pizak, W. E. Trumbull \& H. Schapiro: Influence of Various Gastric Secretory Stimulants on Serum and Urinary Pepsinogen, Am. J. Diges. Diseases, 3 : 6, 417 $-426,1958$.

6) 桜井忠作: ウロペプシンの日内变動, 日新医学, $44: 6,305-312$, 昭 32 .

7) Mirsky, I. A., P. Futterman \& S. Kaplan : Blood Plasma Pepsinogen, II. The Activity of the Plasma from "Normal" Subjects, Patients with Duodenal Ulcer, and Patients with Pernicious Anemia, J. Lab. \& Clin. Med., $40: 2$, 188-199, 1952.

8) Goidsenhoven, G. V., L. Wilkopf, B. S. \& J. B. Kirsner: Serum and Urine Pepsinogen and Gastric Pepsin; Simultaneous Analyses for 24 Hour Periods in Normal Persons and in Patients with Duodenal Ulcer, Gastric Ulcer and Achlorhydria, Gastroenterol., $34: 3,421-435,1958$

9) Hirschowitz, B.I. \& D.H.P. Streeten: Significance of Increased Urinary Pepsinogen (Uropepsin) Excretion during ACTH Administration and in Duodenal Ulcer Patients, J. Lab. \& Clin. Med., 50 : 2, 209-215, 1957.

10) Anson, M. L.: The Estimation of Pepsin, Trypsin, Papain and Cathepsin with Hemoglobin, J. Gen. Physiol., 22 : 1, 1, 79-89, 1938.

11) Chinn, A. B. : Studies on a Blood Serum Proteolytic Enzyme with Particular Reference to Gastric Secretory Function, Gastroenterol., 25 : 1, 14-23, 1953.

12) Hirschowitz, B. I. : Pepsinogen in the Blood, J. Lab. Clin. Med., $46:$ 4, 568-579, 1955.

13) Hoar, C.S. \& J.R. Browning: Plasma Pepsinogen in Peptic-Ulcer Disease and Other Gastric Disorders, New. Engl. J. Med., 255 : 4, 153-158, 1956.

14）桜井忠作, 田辺一雄, 松尾マキ子: 血漿ヘプシノ 一グン測定法の検討, 新潟医誌に発表子定.
15) Van Calcar, R. P. : Ueber die Physiologischpathologische Bedeutung der Weissen Blut Körperchen, Arch. ges. Physiol., $148: 257-263$, 1912.

16) Stadelmann, E. : Ueber Fermente im Normalen Harne, Ztschr. Biol., $24: 226-260,1888$.

17) Leo, H. : Ueber das Schicksal des Pepsins und Trypsins im Organismus, Pflügers Arch. Ges. Physiol., 37 : 223-231, 1885.

18） 1)ょり引用.

19) Kowalewski, K., S.T. Norvell \& W.C. Mackensie: The Gastric Endocrine and Exocrine Response to Histamine in Dogs and Effect of Passage of Blood through the Gastric and Hepatic Vessels on Its Pepsinogen Content, Canad. J. Biochem. \& Physiol., $34: 2$, 244-252, 1956.

20) Fuld, E. und K. Hirayama: Die Ausscheidung der Magenfermente (Lab und Pepsin) durch den Urin, Ztschr. f. exp. Patholog. u. Therapie, $10: 248-278,1912$.

21）日野志郎, 広川竜夫, 片山敬：血獎ヘプシノーグ ンの定量, 日内誌, $46: 4,419-420$, 昭 32 .

22）福地益人：人胃のペプシノーグン分泌火関する 研究，(第 2 編）胃十二指腸突患に扣けるペプシ ノーグン分泌にっいて, 慈惠会医誌, $73: 2,402$ -408 , 昭 33.

23) Spiro, H.M., A.E. Ryan, B.A. \& C.M. Jones: The Relation of Blood Pepsin to Gastric Secretion, with Particular Reference to Anacidity and Achylia, Gastroenterol., $30: 4,563-579$, 1956.

24) Poliner, I. J. \& H. M. Spiro: Confirmation of Achylia by Radioactive $B_{12}$ Uptake and Blood Pepsin Measurement, Am. J. Med., 23 : 6, 894 $-897,1957$.

25) Weiner, H., M. Thaler, M. F. Reiser \& I. A. Mirsky : Etiology of Duodenal Ulcer, I. Relation of Specific Psychological Characteristics to Rate of Gastric Secretion (Serum Pepsinogen), Psychosomatic Med., $19: 1,1-10,1957$.

26) Gryboski, W. A., \& H. M. Spiro: The Effect of Pregnancy on Gastric Secretion, New Engl. J. Med., $255:$ 24, 1131-1134, 1956.

27) Gottlieb, E. : Untersuchungen über die Propepsinmengen im Blut und Harn. Skand. Arch. f. Physiol., 46 : 1-50, 1925.

28) Bornstein, S. \& S. Eichen : Influence of Smoking on Urinary Pepsinogen Excretion, Proc. Soc. Exp. Biol. \& Med., 86 : 3, 619-620, 1954.

29）川島好兼, 永沢滋, 本田利男, 朝倉啓, 岸功, 佐々木

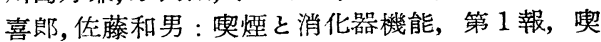
煙の胃液分泌並飞胃運動機能飞及代す影響, 日 消化誌, $53: 6,257$, 昭 31 .

30) Strehler, E. : Die Pepsinogen Ausscheidung in 
Urin, ein Spiegelbild der Peptischen Magenfunktion. Schweiz. Med. Wschr., 84 : 2, 99-103, 1954.

31）黑川利雄, 後藤由夫: 胃液分泌機序, 総合臨床, $5: 2,72-78$, 昭 31 .

32) Varro, V., I. Faredin \& F. Novaszel : Plasma Pepsinogen Concentration and Adrenocortical Activity, Acta Med. Skand., 153 : 3, 211-219, 1956.

33）桐淵道雄：肺結核患者に扣けるウロペプシンの 日内变動, 日新医学 7 月号揭載予定.

34）中西達郎：血漿ペプシノーゲンに関する研究, 第 2 報, 日消化誌, $53: 12,661$, 昭 31 .

35) Kowalewski, K., H.A. Hyde \& S. T. Norvell, Jr. : Effect of ACTH and Histamine on Plasma Pepsinogen in Normal, Hypophysectomized, Thyroidectomized, and Adrenalectomized Dogs, Surg. Forum, $6: 316-320,1956$.

36) 中西達郎：血嶈ペプシノーゲンに関する研究, 第 3 報, 日消化誌，54:5，265，昭 32 。

37) 23) Discussion of Paper by Drs. Spiro, Ryan and Jones, 580-582.

38）竹腰昭道, 石原一郎, 小森義隆 : Stress と Uropepsin (続), 日内分泌誌, $31: 9,544$, 昭 30. K 追加質問.

39) Janowitz, H. D. \& F. Hollander: The Exocrine-Endocrine Partition of Enzymes in the Digestive Tract. Gastroenterol., $17: 4,591-593$, 1951.

40) Gray, S. J., C. G. Ramsey, R. Villarreal \& L. J. Krakauer: Adrenal Influences upon the Stomach and the Gastric Response to Stress, Fifth Annual Report on Stress, 138-169, MD Pub., Inc., New York, 1955/56.

41）竹腰昭道: 胃分泌火及活す内分泌の影響，（第 1 報）健康人に於りる尿及び血清 ヘプシノーゲン 值, 日内分泌誌, $31: 9,544-545$, 昭 30 .

42) 中西達郎: 血嶈ペプシノーゲンに関する研究, 日 消化誌, $51: 10,417-418$, 昭 30 .

43）福地益人：人胃のペプシノーゲン分泌に 関する

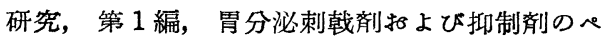
プシノーゲン分泌に及ばす影響について, 慈恵 医誌，73:2，390-401，昭 33 .

44）福地益人：全胃譱犬飞打けるペプシノーゲン分 泌闻する研究, 慈恵医誌, $73: 2,409-415$, 昭 33.

45) Pierach, A. : Die Vegetative Tagesrhythmik und Ihr Bedeutung, Munch. Med. Wschr., 96 : 7, 465-469, 1954.

46) 黒津敏行 : 自律中枢, 日本医事新報, 1445 : 8387, 昭 27 .

47）黑津敏行：自律中枢（J), 自然, $5: 11,2-13$,
昭 25.

48) Euler, U.S. V., S. Hellner-Bjorkman \& I. Orwen: Diurnal Variations in the Excretion of Free and Conjugated Noradrenaline and Adrenaline in Urine from Healthy Subject, Acta Physiol. Scand., 33 : Suppl. 118, 10-16, 1955.

49) Menzel, W. : Über einen 24 Stunden-Rhythmus im Blutkreislauf des Menschen, Acta Med. Scand., 108 : 166-177, 1940.

50) 細谷英吉, 㰌田豊雄: 血液水分及び血清アセチル コリンェステラーゼに及ぼす睡眠の影響(睡眠の 生理及薬理に 関する研究), 第 2 報, 日薬理誌, $46: 4,224$, 昭 26.

51) Polland, W.S. \& A.L. Bromfield: Basal Gastric Secretion in Man, Bull. Johns Hopkins Hosp., 49 : 302-311, 1931.

52) Sandberg, A. A., D. H. Nelson, E.M. Glenn, F. H. Tyler \& L. T. Samuels : 17-Hydroxycorticosteroids and 17-Ketosteroid in Urine of Human Subjects; Clinical Application of Method Employing- $\beta$-Glucuronidase Hydrolysis, J. Clin. Endocrinol. \& Metb., $13: 12$, 14451464, 1953.

53) Torii, T., S. Sasaki, S. Muranaka, T. Moriyama, S. Kusahana \& H. Yoshizawa : 24 Hour Periodicity of Adrenal Corten, Endocrinol. Japoni., 2 : 1, 79-86, 1955.

54) Forsham, P. H., V. D. Raimondo, D. Island, A.P. Rinfret \& R. H. Orr : Dynamics of Adrenal Function in Man, Ciba Foundation Colloquia on Endocrinology, $8: 279-302$, J. \& A. Churchill Ltd., London, 1955.

55) Migeon, C. J., F. H. Tyler, J.P. Mahoney, A. A. Florentin, H. Castle, E. L. Bliss \& L. T. Samuels: The Diurnal Variation of Plasma Levels and Urinary Excretion of 17-Hydroxycorticosteroids in Normal Subjects, Night Workers and Blind Subjects, J. Clin. Endocrinol. \& Metb., $16: 5,622-633,1956$.

56) Bliss, E. L., A. A. Scandberg, D. H. Nelson \& K. Eiknes: The Normal Levels of $17-\mathrm{Hy}$ droxycorticosteroids in the Peripheral Blood of Man, J. Clin. Invest., 32: 9, 818-823, 1953.

57) Doe, R.P., E.B. Flink \& M.G. Flint : Correlation of Diurnal Variation in Eosinophils and 17-Hydroxycorticosteroid in Plasma and Urine, J. Clin. Endoclinol. \& Metb., 14 : 7, 774-775, 1954.

58）渡辺厳一, 木村亮太郎：腎上体皮質機能の日内变 動, ホルモンと臨床, $5: 10,939-947$, 昭 32 .

(受付 : 1959 年 5 月 1 日) 